\title{
Orhan Pamuk'un Hafızasında Bir Melankoli Kaynağı: İstanbul
}

\section{Orhan Pamuk's İstabul Carved in His Memory as a Source of Melancholy}

\section{Kuğu Tekin*}

\begin{abstract}
The focus of the article is the construction of the city image in Orhan Pamuk's memory. The essence of the image of İstanbul in Istanbul Memories and the City appears to be a profound sense of melancholy, which gives way to an equally deep sense of happiness that, Pamuk opines, few other cities could possess. The article then investigates Pamuk's sources of inspiration in creating İstanbul's image which is loaded with melancholy. It is obvious that Pamuk's memories concerning İstanbul have been mainly but not exclusively- shaped by four poets $/$ writers to whom the author sincere expresses his gratitude in the work. The first two are the Turkish authors, Yahya Kemal Beyatli and Ahmet Hamdi Tanpinar, who themselves had been influenced by the other two, Gerard de Nerval and Theophile Gautier. Gautier's travel writings, which he later published under the title of Constantinople had a considerable impact on Yahya Kemal Beyatlı and Ahmet Hamdi Tanpınar, both of whom developed a different and indigenous İstanbul image for its inhabitants. What makes this city image different and original is the combination of the beautiful
\end{abstract}

* Dr. Öğ. Gör.. Atılım Üniversitesi, Fen-Edebiyat Fakültesi, İngiliz Dili ve Edebiyatı, tekinkugu@yahoo.com 
with the bizarre, the miserable and the sordid which brings about a sense of prevailing melancholy rising over the ruins of a collapsed empire. While following the footsteps of his literary predecessors, Pamuk also renders an early autobiography which is interwoven into the cultural, socio-political, and environmental, changes that took place in Istanbul in the twentieth century. The theoretical framework of the article is based on the views of Freud, Kristeva, and Peter Schwenger.

Keywords: Orhan Pamuk, Istanbul, the city, memory, melancholy

\section{Özet}

Bu makale Orhan Pamuk'un Istanbul Hatıralar ve Şehir başlıklı romanındaki melankolik İstanbul imgesinin yazarın hafızasındaki yansımalarını incelemiştir. Yazara göre İstanbul'dan başka çok az şehir bu imgenin yaratığı derin melankoli duygusuna aynı ölçüde eşlik eden mutluluğa sahiptir. Makale romandaki melankoli yüklü İstanbul imgesini yaratırken yazara ilham veren kaynakları araştırmıştır. Görülüyor ki yazarın romanda da minnettarlığını sıkça ifade ettiği başlıca dört yazar Pamuk'un hafizasında yer eden İstanbul hatıralarını biçimlendirmiştir. Bu yazarlardan ilk ikisi Yahya Kemal Beyatlı ve Ahmet Hamdi Tanpınar'dır ve her ikisi de Fransız yazarlar Gerard de Nerval ve Theophile Gautier'in İstanbul izlenimlerinden etkilenmişlerdir. Özellikle Gautier'in Constantinople başlıklı gezi yazıları Yahya Kemal ve Tanpınar'1 derinden etkilemiş ve bu yazarların İstanbullular için farklı ve yerli bir İstanbul imgesi yaratmalarını sağlamıştır. Bu şehir imgesini farklı ve özgün kılan, güzel olanla, biçimsiz, sefil ve acınası olanın bir araya gelerek oluşturduğu melankoli duygusunun, çökmüş bir imparatorluğun kalıntıları üzerinde yükselerek şehre hâkim olmasıdır. Romanda esinlendiği yazarların adımlarını takip eden Pamuk bir yandan da yirminci yüzyıl İstanbul'unda meydana gelen kültürel, sosyal, siyasi ve çevresel değişimlerle iç içe geçen kendi çocukluk ve ilk gençlik dönemlerini hikâye etmiştir. Makalenin kuramsal çerçevesini Freud, Kristeva ve Peter Schwenger gibi yazarların görüşleri oluşturmuştur.

Anahtar sözcükler: Orhan Pamuk, İstanbul, şehir, hafiza, melankoli

Istanbul Memories and the City is an autobiographical work narrating Orhan Pamuk's childhood and youth memories in İstanbul. The thirty-seven chapters of the book mingle the author's memories with the city's history. The recent archaeological discoveries (Yenikap1 excavations) have proven that İstanbul has a history of not 2500 but 8500 years; nevertheless, Pamuk particularly focuses on the cultural, socio-political, economic, and environmental changes that took place in İstanbul in the nineteenth and twentieth centuries. It is clear that İstanbul played a significant role in the formation 
of Pamuk's character and in his choice of profession as an author. The essence of the image of İstanbul in the work appears to be a profound sense of melancholy, which gives way to an equally deep sense of happiness that, Pamuk opines, few other cities could possess. It is obvious that Pamuk's memories concerning İstanbul have been mainly-but not exclusively- shaped by four poets $\mid$ writers to whom the author sincerely expresses his gratitude in the work. The first two are the Turkish authors, Yahya Kemal Beyatlı and Ahmet Hamdi Tanpınar, who themselves had been influenced by the other two, Gerard de Nerval and Theophile Gautier. The İstanbul section of Nerval's Voyage en Orient and Gautier's travel writings, which he later published under the title of Constantinople had a considerable impact on Yahya Kemal Beyatlı and Ahmet Hamdi Tanpınar, both of whom developed a different and indigenous İstanbul image for its inhabitants. What makes this city image different and original is the combination of the beautiful with the bizarre, the miserable and the sordid which brings about a sense of prevailing melancholy rising over the ruins of a collapsed empire.

İstanbul has been regarded, since the middle ages, as a city of contradictions, diversity, and complexity; and it still preserved these characteristics by the time the French authors Nerval and Gautier visited the city in the mid nineteenth century. As Jean Ebersolt remarks in his book about the Byzantine Constantinopolis and Travellers to the Orient (Constantinople Byzantine Et Les Voyageurs du Levant) ${ }^{1}$, İstanbul has always played a vital role as a bridge connecting eastern and western civilizations. The overlapping cultural heritage, Ebersolt claims, of Greek, Roman, Byzantian, and Turkish civilizations, "created this bizarre and sorrowful, exciting and mysterious city, which is neither as pure as Athens nor as rich as Rome" (Ebersolt 1996: 6). Considering the political and socio-economic conditions of Istanbul in the first two decades of the twentieth century, Ebersolt's assumption comparing the city with the two other centers of western civilization appears to be quite convincing: İstanbul was not "as pure as Athens" because of the ethnic diversities the city sheltered, nor "as rich as Rome" due to the devastating outcomes of World War I. Yet when Nerval came to İstanbul in 1843, the Ottoman capital was not under the threat of defeat, poverty, and deprivation; instead, an air of serenity was prevailing in the city. Nerval's journey to the Orient covered Egypt, Lebanon, Syria, Rhodes, Cyprus, İzmir, and İstanbul. İstanbul was Nerval's last destination in the Oriental tour. Only the İstanbul section of Nerval's travelogue was translated into Turkish and published under the title "The Magnificent İstanbul."”2 In his foreword to Nerval's book, R. Özdek remarks that Nerval's work is significant not only because it mirrors the political, socio-economic, and cultural aspects of the Ottoman empire both at the centre and in the provinces, but also because it covers in interview style various national and foreign ideologies in their attempts to settle and legalise themselves in the reformatory so-called Tanzimat (Transformations) period. The book consists of five chapters with the following titles: "On the Way to İstanbul," "Ramadan Nights in İstanbul," "Theater and Entertainment," "The Tale of the Queen of Sheba and the Prophet Solomon," and finally "The Lesser Bairam" (the festival held at the end of 
Ramadan). At the beginning of the section the French poet declares that as soon as he stepped on this Muslim-ruled European land he felt a great relief. The splendid scenery of the İstanbul port, the climate, landscape, lights and colours seem so familiar to the poet that he feels as if he were in the southern regions of his native France.

The first of the two strong motives that urged the French poet to set out for this journey to the east was to leave behind the melancholy of the death of the actress Jenny Colon, Nerval's great but unrequited love; and the second one was the influence of such nineteenth century French romantics as Chateaubriand, Lamartine and Hugo whose works based on the exoticism of the Orient had already founded a solid literary tradition. As stated in Pamuk's chapter entitled "Nerval in İstanbul: Beyoğlu Walks," Nerval is associated with melancholy in French literary culture. However, the İstanbul section of Nerval's travelogue proves that the poet forgets about all his melancholy as he arrives in İstanbul where he stayed for a month during the Ramadan. As also observed by Pamuk, Nerval claims that his İstanbul memoirs differ from the cliche representations of the city reflected in the travel writings of other nineteenth century western authors who stayed in İstanbul for a short time, just visited the tourist sights, and then conveyed their limited impressions of the city in their works. Nerval's intention was to discover a different and original İstanbul image for himself. At those times, the two adjectives, "the exotic" and "the picturesque" came to be habitually used by western authors to define the nonwestern and oriental aspects of the city where they found either in the Beyoğlu district -which was then called "Pera"-or in the traditional touristic locations of the capital, like the Grand Bazaar and the Sultan Ahmet Square. Nevertheless, under the disguise of a Persian merchant, and led by a friend of his, a French painter who had been living in Istanbul for three years, Nerval plunged into the poor neighbourhoods of "old İstanbul." Thus throughout his one-month residence in İstanbul, Nerval saw whirling dervishes in Galata Mevlevi Lodge, watched Karagöz shadow theatre, and listened to story-tellers at cafes, had long walks in the poor neighbourhoods and cemeteries of the city, observed market places, and passers by, Turkish clothes, customs and rituals attentively. Pamuk states that Nerval's wanderings helped him create a profoundly impressive description of İstanbul which would later influence not only western writers of the city like Gautier but also the native ones like Yahya Kemal and Tanpınar. Nerval's inspirational description of İstanbul reads as follows: "İstanbul, which has some of the most beautiful scenery in the world, is like a theatre and best seen from the auditorium, avoiding the poverty-stricken and sometimes filthy neighbourhoods in the wings" (Pamuk 2006: 201).

In 1852, Theophile Gautier, who was a writer, journalist, poet, translator, art critic, and a close friend of Nerval came to İstanbul, stayed for seventy days, and later published his impressions of the capital in a work entitled Constantinople. The title of Pamuk's chapter which is devoted to Gautier is "Gautier's Melancholic Strolls through the City's Poor Neighbourhoods." This chapter follows that of Nerval's and includes Pamuk's reflections concerning Gautier's İstanbul journey, the way the two French authors perceived and experienced the city, and how Gautier's "painterly eye" and rich 
prose style paved the way for the twentieth century Turkish authors like Yahya Kemal Beyatlı and Ahmet Hamdi Tanpınar who would later be called the two greatest İstanbul poets. Pamuk states that in addition to his mastery in turning images into words, Gautier "had the sort of eye that could find melancholic beauty amid dirt and disorder" (Pamuk 2006: 205). Unlike Nerval, who attached his sense of melancholy to the shores of Niles, Gautier found the same feeling in the poor neighbourhoods of İstanbul cradling the ruins of the long-vanished Roman and Byzantine civilisations. It is noteworthy that at the end of his discussion of the subject Pamuk replaces the word "melancholy" with its Turkish equivalent "hüzün": “... the roots of our hüzün are European: the concept was first explored, expressed and poeticised in French (by Gautier, under the influence of his friend Nerval)" (Pamuk 2006: 210). The shift from melancholy to hüzün foreshadows the theme of the subsequent chapter where Pamuk recounts a period of radical transformation in Turkish history marked by the collapse of the Ottoman Empire and the foundation of the new secular Republic of Turkey in 1923.

The twenty-fifth chapter, "Under Western Eyes", covers the socio-cultural changes that took place in Istanbul within 150 years. In this chapter Pamuk appears to be severely critical of the Westernisation project of the "little, imitative Republic of Turkey" which replaced the Ottoman Empire. The founders of the republic attempted to construct a new Turkish identity which would meet the needs of the rising nationalistic spirit all over the country. This construction of new Turkish identity was realised through the rejection of the Ottoman history and cultural heritage, as well as through the enforcement of a series of reforms that imposed new cultural codes on the society whose memory had been thus reformatted, in a sense. Pamuk claims that the end of the imperial rule and the beginning of the republican era brought Istanbul nothing but isolation. Pamuk's comment on the impact of the transition period on the city is as follows:

"When the Empire fell, the new republic while certain of its purpose was unsure of its identity; the only way forward, its founders thought, was to foster a new concept of Turkishness, and this meant a certain cordon sanitaire from the rest of the world. It was an end of the grand polyglot, multicultural İstanbul of the imperial age; the city stagnated, emptied itself out, and became a monotonous, monolingual town in black and white" (Pamuk 2006: 215).

Pamuk states that in the general western view the exotic allure of İstanbul was lost to the nineteenth century Ottoman modernisation process and the twentieth century Westernisation project of the Turkish republicans. Within this process of change, which lasted 150 years, what remained unchanged were the street dogs and the melancholy atmosphere of İstanbul. It could be said that İstanbul's street dogs bear a strong resemblance to the ruins and remains that obstinately withstand the passage of time. Perhaps this is the reason why they draw the attention of all the five melancholy authors discussed herein, who have been likewise enchanted by the city's ruins. In this respect, it is a lucky coincidence that melancholy has been traditionally symbolised by the 
image of the black dog. But how did the melancholy atmosphere and the street dogs become the two complementary images of İstanbul? Linda Michael's article, "Black Dog: The History of an Expression," which sketches the history of the phrase "black dog" from classical to modern times in literature and folklore, draws attention to the shared obstinate characteristics of the dog figure and melancholy as follows: "The idea that melancholia is not easily shaken off is given life by the image of the faithful, though menacing, dog. The image accords with the divided attitude towards dogs in ancient Greece and Rome, where they were considered both loyal and treacherous, intelligent and stupid, vigilant and negligent" (Michael 2005: 2). Obviously, the melancholy and street dogs of İstanbul are marked by such common qualities as endurance and resistance against time and change; both appear to be chronic; both represent a psychic state of inbetweenness; and, both embody contradictory notions, sentiments and attitudes just like İstanbul. Ekrem Işın in his Everyday Life in İstanbul devotes a chapter to the street dogs of the Ottoman İstanbul. The title of the chapter is "Street Dogs of İstanbul: The fourlegged Municipality," and it highlights the role of İstanbul's dog colonies in the city's social life as follows:

"Among the diverse species that populate İstanbul, dogs have contributed at least as much as humans to the city's social history. They have established their own independent colonies and councils of elders; they have solved problems of security and government at high levels of expertise; and they have developed ethical values and practised a common life philosophy with unfailing integrity" (Işın 2001: 219).

In addition, Chevalier and Gheerbrant's Dictionary of Symbols interprets the symbolic significance of the dog in astrological terms as follows:

The thirteenth and final constellation in the ancient Mexican zodiac was the constellation of the dog. It induces not only notions of death, of the end and of the underworld, but also of initiationan of rebirth, for, in the words of the French poet, Gerard de Nerval, 'the thirteenth comes full cycle and is first again' (Işıı 2001: 297).

It is seen that Nerval points to the infinite possibilities of beginnings and endings in İstanbul through the image of the dog.

In chapter twenty-six, "The Hüzün of the Ruins: Tanpınar and Yahya Kemal in the City's Poor Neighbourhoods," Pamuk this time talks about the two Turkish writers' İstanbul excursions during the armistice years and in the early part of the republican era. Yahya Kemal Beyatl1 (1884-1958), bearing such titles as the "supreme craftsman," or "the greatest of İstanbul poets," wrote poems of love, nostalgia for the Ottoman past, the beauties of İstanbul, and the metaphysics of life and death through a highly refined and melodious language. Similarly, his student and friend Ahmet Hamdi Tanpınar (19011961 ) is the author of some of the most memorable lyric poems, novels, and prose works produced by the twentieth century Turkish writers. Both Yahya Kemal and Tanpinar spent a long time in France studying French literature. Particularly, Yahya Kemal stayed 
in Paris between 1903-1912. Both writers, in tune with the political project of the newly founded Turkish Republic, concentrated their efforts on the creation of an indigenous and original İstanbul image, one in which the inhabitants could see themselves. Ironically, these nationalistic attempts at highlighting the Turkish identity of the city were heavily influenced by the travel accounts of the two foreigners, Nerval and Gautier. It was Nerval who first thought that the poor quarters of the city were also worth exploring; Nerval sensed the possibility of creating an aesthetic city image out of the bizzare, filthy, and poor. Yet it was his friend, Gautier, who nine years later showed western readers that those poor neighbourhoods were no less important than the scenic views of the city in his book Constantinople. Finally, following in the footsteps of Nerval and Gautier, Yahya Kemal and Tanpinar completed the melancholy image of the city's poor neighbourhoods by adding the senses of loss and defeat. In the same chapter Pamuk quotes from Tanpınar's "A Stroll Through the City's Poor Neighbourhoods" in order to show how the author touches upon İstanbul's beauty and symbolic significance: "I see the adventures of these ruined neighbourhoods as symbolic. Only time and the sharp shocks of history can give a neighbourhood such a face. How many conquests, how many defeats, how many miseries did its people have to suffer to create the scene before us?" (Tanpinar qtd. in Pamuk 2006: 224). It is important to note that here Tanpınar's hüzün is not a subjective sentiment generated by reflecting on the defeats andlor conquests that mark the lifetime of one or more civilisations; it rather stems from witnessing the presence and the overwhelming flow of time in the materialised form of these ruins. To put it simply, Tanpınar observes the visible and deep-set traces of time in these neighbourhoods where he finds "as traditional, unspoiled and untouched by the West," (Pamuk 2006: 227) and despite their poverty and wretchedness, Tanpinar believes, they preserved their peculiar style and way of life. Here, it might be possible to draw a parallel between the type of melancholy experienced by Tanpınar and Yahya Kemal and Peter Schwenger's description of melancholy associated with physical objects. In his introduction to The Tears of Things: Melancholy and Physical Objects Schwenger distinguishes between the two types of melancholy: the first one is the traditional lament for the ephemeral object, and the second is the one that is produced "by the act of the perception of the object by the subject" (Schwenger 2006: 2). Schwenger claims that: "[This moment of] perception, always falling short of full possession, gives rise to a melancholy that is felt by the subject and is ultimately for the subject. It is we who are to be lamented, and not the objects that evoke this emotion in us without ever feeling it themselves" (Schwenger 2006: 2). Hence, while Gautier's melancholy might be regarded as the traditional lament for the transient object because it stems from the French poet's sorrow felt before the ruins of the two Western originated civilisations, the two Turkish authors mourn for themselves, and more accurately in a metonymical mode, for the Turkish nation.

The İstanbul section of Tanpınar's Five Cities is accepted as one of the rare sources written about life in İstanbul in the past as well as in the first half of the twentieth century. The author's detailed observations and realistic descriptions inform the reader about 
the climate, paysage, architecture, culture, social structure, multifarious life styles, and literary, artistic, and intellectual history of the city. As for Yahya Kemal, his most famous İstanbul poem, "Beloved İstanbul," is worth mentioning here, even though Pamuk did not refer to the poem in his work. The poem is an elaborate expression of Yahya Kemal's love of the city wherein the poet confesses not to have disliked any neighbourhood that he has visited. He declares that no other city could replace İstanbul which is the only city that he will love until the end of his life. Yahya Kemal asserts in the poem that knowing intimately even one single neighbourhood of the city is such a rich and fulfilling experience that equals a lifetime. The poet considers a life spent in İstanbul to be dreamlike. Particularly, the last two lines of the poem indicate the poet's two different treatments of time spent in İstanbul, the city of enchanting beauties. Martin Stokes in his "Three Versions of Beloved İstanbul" interprets the presence of two kinds of time in the poem as follows: "One might perceive a tension in the poem between two different kinds of time, one is an orderly historical progress in which love begins, develops, and reaches maturity and repose after long experience. The other kind of time is a stepping out of time, as if into a dream-a significantly more unstable prospect" (Stokes 2010: 159). Motivated by the exemplary realistic literature of the young Turkish Republic, some authors left İstanbul in order to reflect the "real" life in the Anatolian villages. This tendency towards a realistic literature served republicans' desire to record and reform life in the Anatolian countryside. However, authors like Yahya Kemal and Tanpinar resisted this realist impetus and kept producing works in İstanbul. And, for those who stayed in İstanbul, as Stokes states, "the city became the locus of a distinct and complex phantasmagoria, approached via dream, fantasy, [and] reminiscence ..." (Stokes 2010: 5).

This dream-time experienced by the three Turkish writers of melancholy in İstanbul might be better understood in the light of Julia Kristeva's Black Sun. Kristeva foregrounds the distinguishing traits of a melancholy mind's perception of spatio-temporal relations, and states that to a melancholy person, the notion of time is distorted. Time does not flow; it is immobile and fixed upon a certain moment or period, a certain space, and a certain memory: "massive, weighty, doubtless traumatic because laden with too much sorrow or too much joy, [Kristeva reflects,] a moment blocks the horizon of depressive temporality or rather removes any horizon, any perspective" (Kristeva 1989: 60). Certain segments of time and place hold the melancholy mind captive due to either a great joy or a great sorrow. Kristeva then refers to Kant to emphasise the idea that depression is dependent on time rather than place: "Considering the specific variant of depression constituted by nostalgia, Kant asserted that nostalgic persons did not desire the place of their youth but their youth itself' (Kant qtd. in Kristeva 1989: 60). Hence it would not be wrong to claim that a return to a dream-time İstanbul has been carved in the common memory of all the three Turkish authors discussed herein. Obviously, neither the pains of World War I, nor the homogenising ideologies of the republican era could change the melancholy beauty of İstanbul image in the memory of the three authors of the city.

But what is the connection between melancholy and the faculty of finding 
beauty in the ruined, poor, and filthy? Why did the five authors mentioned in this paper persistently walk in the ruined, impoverished quarters of İstanbul where one can see the wreckage of three successive empires? And why were the five authors haunted by melancholy during their walks? The answer to these questions might perhaps be found in the two essays by Freud, both published in the last years of World War I. The first one in which Freud defends the everlasting quality of beauty is On Transience. Contrary to the common belief in the transient and hence sorrowful nature of beauty, Freud claims in the essay that the notion of beauty is defined not by transience but by endurance. Paradoxically, beauty is not only resistant to temporal limitation but also immune to all sorts of material damages like those caused by wars or natural disasters. What is considered to be beautiful and perfect may undergo material damage or even vanish entirely. But material damage or loss neither diminishes the value of the beautiful object nor changes the way it was and is still remembered. Hence Freud draws the conclusion that "our high opinion of the riches of civilisation has lost nothing from our discovery of their fragility" (James ed. 1957: 307). Therefore, one possible explanation might be that what the five authors saw in the Old İstanbul was not a wreckage to be mourned after, but a timeless beauty and perfection created and destroyed by various civilisations. Also Freud's Mourning and Melancholia sheds light on why those İstanbul walks were accompanied by melancholy. As Freud remarks, melancholy differs from mourning in that it is characterised by a feeling of self-reproach resulting from the loss of the loved object. This kind of self-reproach, guilt, or responsibility for the loss of the object is absent in mourning (James ed. 1957: 244). The old and bizarre İstanbul makes the five authors directly experience man's power to create as well as to destroy great civilisations. This experience inspires a simultaneous exaltation and sorrow, the former for the majestic works that man is capable of, and the latter for the fragility of such works. When a sense of personal responsibility is adjoined to the sorrow in face of destruction, melancholy is born. As Nerval muses, "İstanbul is a bizarre city! Magnificence and poverty, tears and joy, more control than exercised anywhere else and, at the same time, greater freedom than found anywhere else are all intertwined" (Nerval 1974: 15).

\section{Endnotes}

${ }^{1}$ I translated J. Ebersolt's quotations from Turkish into English.

${ }^{2}$ I translated G. de Nerval's quotations from Turkish into English.

\section{Works Cited}

Chevalier, J. and A. Gheerbrant (1996) The penguin dictionary of symbols. Trans. J. B. Brown. London: Penguin.

Ebersolt, J. (1996) Bizans İstanbulu ve doğu seyyahları (Constantinople Byzantine et les voyageurs du levant). Trans. İ. Arda. İstanbul: Pera. 
Işın, E. (2001) Everyday life in İstanbul. Trans. Virginia Taylor Saçlıoğlu. İstanbul: Yapı Kredi.

Kristeva, J. (1989) Black Sun: Depression and melancholia. Trans. Leon S. Roudiz. New York: Columbia University.

Michael, L. (2005) Black Dog: The history of an expression. 25 July 2013 Blackdoginstitute. org. 1-13., January. Web.

Nerval, G. de. (1974) Muhteşem İstanbul (Voyage en Orient). Trans. R. Özdek. İstanbul: Boğaziçi.

Pamuk, O. (2006) Istanbul memories and the city. Trans. M. Freely. London: Faber and Faber.

Schwenger, P. (2006) The tears of things: Melancholy and physical objects. Minneapolis: University of Minnesota.

Stokes, M. (2010) Three versions of beloved İstanbul. The Republic of love cultural intimacy in Turkish popular music. Chicago: The University of Chicago, 147-189.

Strachey, J., ed. (1957) On Transience. The Standard Edition of the Complete Psychological Works of Sigmund Freud: On the History of the Psycho-Analytic Movement, Papers on Metapsychology and Other Works. XIV (1914-1916): 303-309. London: The Hogarth Press and the Institute of Psychology.

Strachey, J., (1957) Mourning and Melancholia. The Standard Edition of the Complete Psychological Works of Sigmund Freud: On the History of the Psycho-Analytic Movement, Papers on Metapsychology and Other Works. XIV (1914-1916): 237-239. London: The Hogarth Press and the Institute of Psychology. 